\title{
Assessment of Hospitality Industry Evolution and Development in the Russian Federation
}

\section{Konstantin B. Kostin}

\author{
Fulbright Faculty Development Program Alumnus, University of North Florida \\ Full Professor, Faculty of Economics and Finance, Saint-Petersburg State \\ University of Economics Sadovaya, Petersburg, Russia
}

\author{
Correspondence should be addressed to: Konstantin B. Kostin; kost_kos@mail.ru \\ Received date: 4 January 2018; Accepted date: 26 May 2018; Published date: 02 July 2018 \\ Academic Editor: Angi Erastievich Skhvediani \\ Copyright (C 2018. Konstantin B. Kostin. Distributed under Creative Commons CC-BY 4.0
}

\begin{abstract}
The purpose of this article is to assess the evolution and development of hospitality industry in the Russian Federation. The problems and prospects of the hospitality industry development under modern market conditions in modern Russia are investigated. The major challenges for hospitality industry development were identified and examined: lack of investment; lack of sophisticated marketing programs; lack of innovative technology adoption; lack of qualified personnel. The solutions to the detected challenges were proposed and discussed. The roadmap and prospects for sustainable hotel business growth in the Russian Federation are presented.
\end{abstract}

Keywords: hospitality, tourism, hotel business, economic growth, economic prospects.

\section{Introduction}

The tourism industry, which encompasses hotels, travel agencies, food and trade enterprises, construction of tourist attractions, transportation, and educational institutions which train hospitality professionals, represents one of the most dynamically developing fields of the world economy today (Bowie, D., Buttle, F., 2004; Cochrane, J., 2010; Farrell, B., \& TwiningWard, L., 2005). This rapid development is based on the renewal of production potential (utilization of scientific technical innovations and information technologies), the enhancement of the quality of education of hospitality personnel, and especially on the research and implementation of new technologies, strategies and approaches to business administration (Avanusova, G.A., 2007; Heide, M., Gronhaug, K., 2009).

At the same time, permanent accumulation of material assets being used in the global market as a resource for competitive

Cite this Article as: Konstantin B. Kostin (2018)," Assessment of Hospitality Industry Evolution and Development in the Russian Federation", Journal of Eastern Europe Research in Business and Economics, Vol. 2018 (2018), Article ID 471337, DOI: 10.5171/2018.471337 
advantage, volatility and instability of the market (related mostly to the consequences of the 2008 financial crisis) and possible retargeting of consumer preferences, all contribute to making the problem of flexible and efficient management extremely acute (Johannesson, J., Palona, I., 2010; Susilovic, A., Sertic, M., 2010).

This problem is especially significant for modern Russia, where the hospitality industry is still in the developmental stage (Mel'nikov, D.V., 2012). One of the main challenges of the Russian hospitality industry during the Perestroika period in the 1990's was the application of the global business standards to Russian enterprises, which had never functioned under a market economy. The dictatorial administrative system that used to manage the country had collapsed and the transition to the new management system under complex economic conditions required solutions to new issues, related to the necessity for an adequate comprehensive business response to the changes in both the internal and external operations of the Russian hospitality industry enterprises.

Unfortunately, research in the field of creating relevant methodology and algorithms, which could be used as a roadmap for comprehensive performance enhancement in the hospitality industry given the specifics of the Russian business environment, is of a scattered and fractional nature; there is no solid methodological vision of relevant competitive strategies formation for Russia in the field of hospitality management. Therefore, the forthcoming of each new publication dedicated to the analysis and definition of ways and conditions for successful business development in the Russian hospitality industry is crucial.

\section{The analysis of the current state of the hospitality industry in Russia}

Currently, the hospitality industry significantly contributes to the economic development of Russia as well as to the quality of life of its population (Mel'nikov D.V., 2011). According to its scale of operation and turnover, the hotel and tourism business forms one of the leading industries in the country with a steady growth potential. The total contribution of Travel and Tourism to GDP was 4,197.2 billion rubles (USD 62.2 billion) which represented $5.0 \%$ of GDP in 2016. The total contribution of Travel and Tourism to employment, including jobs indirectly supported by the industry was $4.7 \%$ of total employment $(3,365,500$ jobs $)$. As it is well known, the main development trends of the world hospitality industry are globalization and integration of businesses, ultimately leading to the establishment of larger corporations (hotel consortiums) and hotel chains (Cheng-Hua, T., et al, 2009; Putilina E.L., 2011). In Russia, hotel chains started to develop in 2000 under complicated conditions of market economy formation in the country as a whole. The evolution of hospitality business from 2000 to 2016 is presented in Figure 1

Konstantin B. Kostin (2018), Journal of Eastern Europe Research in Business and Economics, DOI: $10.5171 / 2018.471337$ 


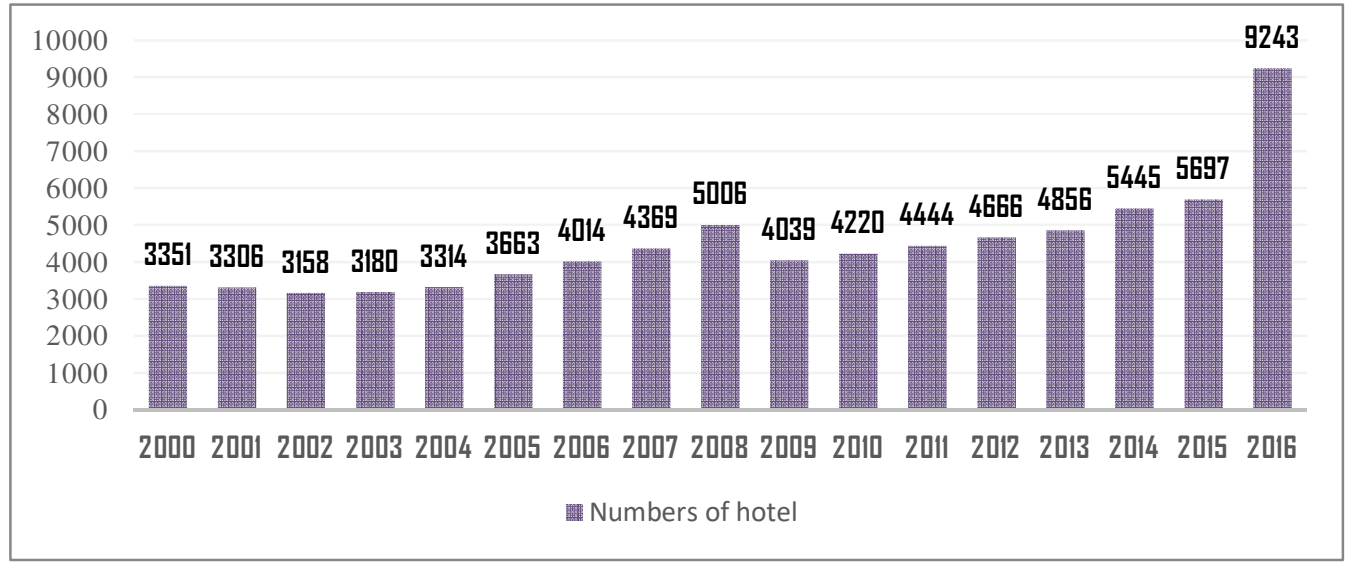

Fig. 1: Growth of hospitality business in Russia (number of hotels). (Created by author based on the data acquired from Russia statistical yearbook, 2017, ROSSTAT, 2017).

Figure 1 presents the evolution of hospitality industry by hotel numbers from 2000 to 2016. It could be concluded, that over the last 16 years the number of hotels has grown by $276 \%$. In order to understand the essence of the problems which the Russian hotel and tourism industry is currently facing in the ongoing transition towards a market economy, it is necessary to account for both macroeconomic and microeconomic factors. The most crucial market reforms carried out by the Russian government during the process of Perestroika at the macro level are the following: price liberalization, dismantling the centralized government system, changing financing and resource allocation principles, establishment of the new banking system, and privatization (Skobkin, S.S., 2002). One of the most significant outcomes of the reforms was the decentralization of management and decision making in the hospitality and tourism industry of the country. The elimination of administrative control over decision making at the micro level was one of the most important achievements in liberating business management in the hospitality industry.

The emergence of international hotel chains in the Russian market served as a catalyst for development and modernization of the hospitality industry in Russia, as well as for the emergence of domestic hotel chains. The market share of the international hotel chains constitutes about $10 \%$ of the total amount of hotels in Russia (InterContinental Hotels Group (IHG), 2011). The domestic hotel market is dominated by the old soviet-style hotels, which constitute $60 \%$ of the market, whereas the market share of totally renovated domestic hotels does not exceed $8 \%$. The transition to chain hotel management is occurring at the same time as the Soviet-period hotels are being renovated and transformed into modern hotel complexes, in compliance with the global international standards. The indicator of hotel rooms in Russia stood at 4.5 rooms per 1000 inhabitants, whereas in Europe the same indicator is $13-35$ rooms per the same number of inhabitants (Kostin, K.B., 2012, article). Despite the difficulties the tourism and hospitality industry is currently undergoing under the market economy, it is nevertheless in the process of total reconstruction with the target of satisfying the modern industry standards (Kostin, K.B., 2016, monograph). The emergence of national hotel chains cannot be considered to be a "mass movement", and Russian hotel companies do not yet have the same appeal as foreign hotel companies do. Nevertheless, it is worth mentioning the success of the Russian national hotel operators like "Amaks", "Azimut", and "Heliopark".

Konstantin B. Kostin (2018), Journal of Eastern Europe Research in Business and Economics, DOI: $10.5171 / 2018.471337$ 
During the period from 2005-2010 the number of hotel complexes in Russia increased by $50 \%$. According to the Russian Hotel Association (RHS), in the near future, the number of national hotel chains is going to steadily grow. This process is constantly stimulated by the international hotel operators in the Russian market. They set the standards and implement the technology which provides for high quality service, hence serving as the model for national hotel chains in enhancing management efficiency of Russian hotel chains and contributing to continuous development of the hospitality industry. Following the weakening of the Russian ruble in the second half of 2014 the hotel market suffered a significant fallout, reporting a 20.1\% RevPAR drop for the full year of 2016. This result was mainly driven by occupancy levels, which fell $15.3 \%$, coupled with a $5.7 \%$ drop in rate. Performance started recovering over the subsequent years, with 2016 seeing a 24.0\% RevPAR uplift compared with 2014, bringing it just $0.6 \%$ below the country's year-end 2013 RevPAR level (in 2014 the national currency had weakened). Russia's performance has been relatively strong in 2017, with RevPAR 9.3\% higher than it was during 2013, indicating that the market has stabilized (Russia hotel and tourism investment conference, 2017).

The Moscow and Saint-Petersburg hotel markets have a major effect on the state of the hospitality industry of the country in general. Currently, according to RHS, Moscow and St. Petersburg comprise 70\% of the total hotel market turnover in Russia. The market share of 5 star hotels in both cities is only $7-7.6 \%$, whereas the $2-3$ star hotels, or the hotels without a rating, are in highest demand with an average occupancy of $80 \%$ per year. Nevertheless, both megalopolises concentrate on building up the number of premium class hotels, i.e. the establishment of hotels for travelers with high income. This is justified by the fact that the majority of Moscow and St. Petersburg hotel guests are foreigners and well-to-do Russians, who come for business or tourist purposes. The business tourism structure is well developed in both cities. The foreign and Russian business travelers, when visiting the megalopolises, prefer to stay at 4-5 star hotels, which have not only the capabilities to host guests, but also have facilities for conducting business negotiations: at least several conference halls with cutting edge equipment. The average annual occupancy of the premium class Moscow hotels is close to average annual occupancy of the same level of European hotels - 57\%; the summer average occupancy reaches $95 \%$. A similar situation is observed with the leading middle class St. Petersburg hotels, which satisfy the European quality service standards. The desire of Western hotel chains to increase their presence in Moscow and St. Petersburg can be explained by high profitability margins, which, in turn, is the consequence of overstated prices, due to the lack of competition in the economy class market sector.

The national hotel business builds up its presence in larger cities under tough competitive conditions with international hotel chains in the medium price range market segment and aims at wide geographical representation in different regions of Russia. However, $80 \%$ of the modern hotel market in the regions in Russia is comprised of the old hotels, constructed in the Soviet times. There is a great need for new hotels equipped up to modern hospitality standards - typically 3 star hotels. The main regional market segment is mainly comprised (about 87\%) of business travelers who travel within Russia. The growth in business tourism volume, which is rapidly expanding in the megalopolises and larger cities in Russia, significantly contributes to the increase in hotel business development in the cities. The breakdown of hotel composition in Russia is as follows: up to $60 \%$ of the hotel stock is located in the cities and up to $34 \%$ in rural areas. In the villages, rural tourism is winning its market share, which became an indisputable driver of the regions' economic development. Most of the regions in Russia have significant potential capabilities for recreational, culturalcognitive, ecological etc. tourism (Vlasova T.V., 2013; Shubaeva, V.G., 2013). Experts estimate the averaged index of the tourist

Konstantin B. Kostin (2018), Journal of Eastern Europe Research in Business and Economics, DOI: $10.5171 / 2018.471337$ 
potential of Russia to be $55.8 \%$. Such a high number demonstrates that more than half of the landscape, geographical and climate resources of Russia could be used for the development of various tourist destinations, subject to the needs of the tourists. Along with these development trends, numerous opportunities emerge for alternatives to hotel chain business model - specifically for mini-hotels, which are becoming more in demand by the national hospitality industry due to their high efficiency, lower prices and growing demand for tourism services. The minihotel business does not require significant initial investment and complex strategic tasks solutions; it is not labor consuming in management and execution (Schianetz, K., \& Kavanagh, L., 2008). This business is designed for inexpensive mass tourism and would satisfy the demands of a wide spectrum of clients traveling within Russia by bringing them closer to sightseeing locations and by providing them with everything needed for a comfortable stay. Moreover, this business is not just limited to the resources of large corporations and municipal unions, but it makes it possible for small companies and individual entrepreneurs to establish themselves in the market (Vlasova, T.V., 2013). The operation of such entrepreneurs plays a positive role in hotel market development, not only in rural areas, but also in big cities such as St. Petersburg, by creating minihotels out of apartments located in the city center (Kostin, K.B., 2012, article). The 3star market segment becomes much more appealing to both Russian and foreign investors, namely because the projects in this market segment generate superior returns and the project's breakeven point in typically reached faster. It is also important to mention that domestic tourism has been a driving force for Russia's hotel performance in recent years. This growth has been driven by the weakening ruble, along with restrictions on outbound travel to Egypt and Turkey, popular destinations for Russian tourists. This has benefited a number of Russian markets, including Moscow, St. Petersburg and Sochi (Russia hotel and tourism investment conference, 2017). The key development areas in the Russian hotel market nowadays are in the construction of large multifunctional complexes, standard hotel construction projects in the regions outside of Moscow and St Petersburg, construction of mini-hotels, and reconstruction of soviet style hotels. Figure 2 presents the current composition of the hospitality industry in Russia.

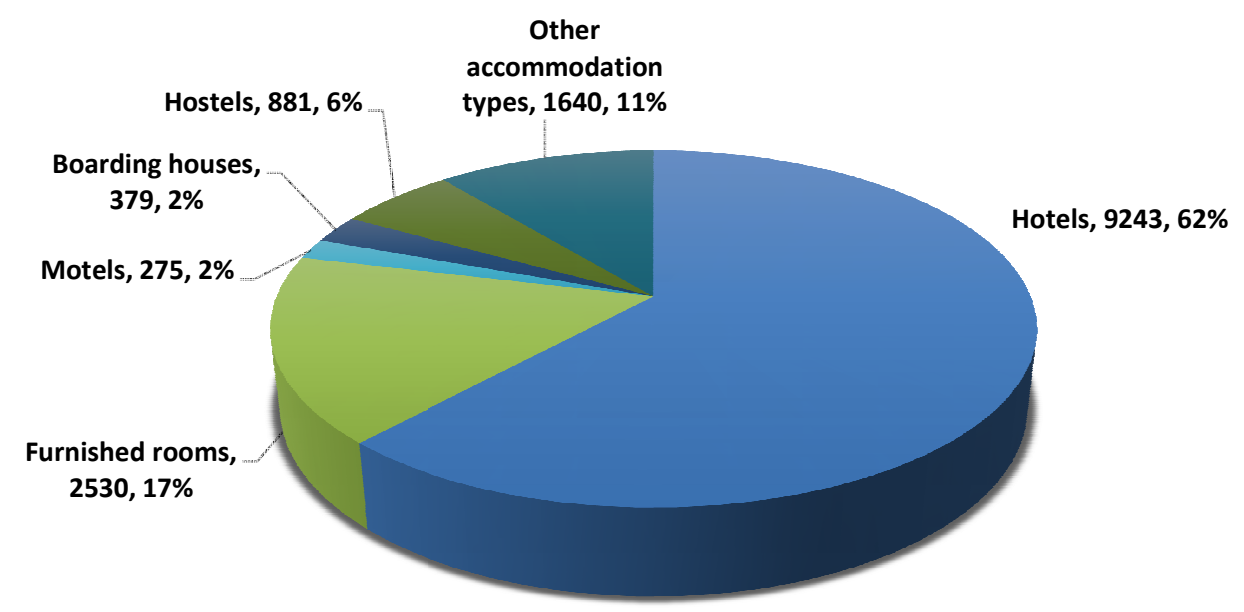

Hotels $\square$ Furnished rooms $\square$ Motels $\square$ Boarding houses $\square$ Hostels $\square$ Other accommodation types

Figure 2: Contemporary composition of the hospitality industry in Russia, 2016 (Created by author based on the data acquired from Russian statistical year book, 2017, ROSSTAT, 2017).

Konstantin B. Kostin (2018). Iournal of Eastern Eurone Research in Business and Economics. 
Based on the analysis of the data presented in Figure 2, it could be inferred that the market economy showed noteworthy progress in Russia over the last almost 2 decades. A whole new marketing segment of furnished rooms and other accommodation types, which in total currently represents 4170 units or $27,9 \%$ of the hospitality market in Russia was formed. This means that the shared economy concept is picking up speed in Russia, with companies like AirBnb winning their market share and competing against the tradition hospitality industry representatives.

However, despite the obvious progress in the development, the hospitality industry in Russia according to world standards remains at the introductory formation stage. Let us try to analyze the reasons for this phenomenon. It is well known that the general condition of the country's economy has a major impact on the state of any economic sector including the hospitality industry (Kang, K.H., Lee, S., Huh, C., 2010). The modern Russian economy is still characterized by the imperfect ownership structure (imperfections in the legislature regulating the ownership management), an underdeveloped labor market, outdated fixed capital, financial and organizational problems, and lack of fair competitive conditions (Skobkin, S.S., 2002). The inequality of competitive conditions takes different forms: inequality in preference provisions, unequal allotment conditions for industry project construction, creation of favorable occupancy mode for tourists for particular hotel businesses, unequal commercial building rental pricing and energy resource pricing, unequal administrative regulation of the application of the law etc. There is no mechanism to regulate the complexities of interactions between the different sectors, in particular between the hotel administration and tour operators, typically accompanied by violations of the agreement conditions. Additionally, as a result of the world's financial crisis, the financial situation in the hospitality industry has changed to the worse: the level of investments has decreased, the occupancy rates have gone down, and the demand for premium class hotel services has decreased. This has led to the revision of the dimensions and timeframes for many projects, and in some cases, even to the sales of hospitality assets. Let us analyze a number of specific problems, which the modern tourism and hospitality industry in Russia faces and denote the approaches to solving them.

\section{Problem Statement}

Let us define the most critical challenges the hospitality industry in Russia is currently facing, given that the Russian economy had transitioned from the command administrative system to the market conditions just a few decades ago, had undergone the financial crises of 2008 and suffered from the weakening of the ruble in 2014 as a result of the decrease in the oil prices and the imposed sanctions by the Western countries. These problems are revealed below:

1) lack of investment;

2) lack of sophisticated marketing programs;

3) lack of innovative technology adoption;

4) lack of qualified personnel.

In the next section, relevant investigation will be conducted; the solutions to the defined challenges will be proposed and thoroughly discussed. The long-term forecast for successful hotel business development in Russia will be presented based on the investigation.

\section{Investigation Framework and Proposed Solutions}

The Approaches to Solving the Developmental Problems of the Russian Tourism and Hospitality Business

Increasing the Investment Volume

The challenges defined in the previous sections create extremely complex conditions for investment activity development and enhancement. Investment activity can only be considered

Konstantin B. Kostin (2018), Journal of Eastern Europe Research in Business and Economics, DOI: $10.5171 / 2018.471337$ 
successful when the main investor interest growth conditions are met - when the demand exceeds supply. The increase in the investment's volume characterizes the competitiveness of the economy (Arnold, G., 2007). Investments open up production expansion opportunities, capital renewals, new technology development and implementation, production quality and competitiveness enhancement (Aleshin, V.A., et al, 2010). The investor's goal is to invest the financial resources "today" in such a way that "tomorrow" will bring maximum return with minimum associated risk (Jackson, Ch., 2006). Nevertheless, it is very difficult for the investor to make the right decision without the assessment and analysis of the investment assets under the market conditions where multiple companies are present in the market and information is accessible in abundance. The term investment attractiveness is used for investment suitability assessment, selection of the alternatives and determination of resources' allocation efficiency (Bystrov, S.A., 2008; Tkacheva, Ya.S., 2011). The methodology formation for investment attractiveness assessment is currently at the introductory stage in Russia. The problems of systematic investigation of investment activity development mechanisms, investment flow management, efficiency enhancement and approaches to investment attractiveness assessment establishment are present in Russia. Travel and Tourism investment in 2016 was 396.2 billion rubles, which constituted only $2.1 \%$ of the total investment (USD 5.9 billion) (World Travel and Tourism Council, 2017). Attracting investments necessary for the development of national hospitality industry in accordance with the world standards requires a systematic approach, as well as conduction of a fundamental analysis with consideration of the specificity of this industry. As illustrated by the investment figures above, the problem of investment attractiveness is especially acute in the hospitality and tourism business. In the course of the research which was conducted, the strategy of hotel business enterprises' investment attractiveness assessment was developed and the assessment algorithm was designed (Kostin, K.B., 2016). For the algorithm design, the key indicators, which characterize the financial conditions of any tourism/hospitality enterprise were used (Bragg, S.M., 2007; Block, S.B., Hirt, G.A. 2003). The methodology of assessing the current financial state of tourism/hospitality entities was proposed.

Investments in tourism and hospitality business allow establishing new tourist properties by means of new capital, modernizing or reconstructing the existing stock which provide and produce specific types of tourist and hospitality services, and also applying the capital towards intangible assets (inventions, know how, etc.). This can only be possible if there is supply and demand for investments, and the interests of all participants of the investment process match, i.e. everybody benefits from it (Fabozzi, F.J., Markowitz, H.M., 2011). The comparative data on the investment volume for the first three quarters of 2015 and 2016 for the European and Russian hospitality market are presented in table 1.

Table 1: Investment in hospitality real estate, end of third quarter of 2016. (Created by author based on the data acquired from Geraschenko, E., 2016)

\begin{tabular}{|l|l|l|}
\hline \multicolumn{1}{|c|}{ Country / Region } & \multicolumn{1}{|c|}{$\begin{array}{c}\text { Total amount of investment } \\
\text { (millions of euros) }\end{array}$} & \multicolumn{1}{c|}{$\begin{array}{c}\text { Gain/loss on a yearly } \\
\text { basis (\%) }\end{array}$} \\
\hline Germany & 856 & -38 \\
\hline Great Britain & 305 & -75 \\
\hline France & 238 & -39 \\
\hline Spain & 537 & 162 \\
\hline
\end{tabular}

Konstantin B. Kostin (2018), Journal of Eastern Europe Research in Business and Economics, DOI: $10.5171 / 2018.471337$ 


\begin{tabular}{|l|l|l|}
\hline Italy & 285 & 135 \\
\hline Ireland & 155 & 106 \\
\hline Countries of Scandinavia & 237 & 17 \\
\hline Central and Eastern Europe & 149 & -6 \\
\hline Countries of Benelux & 125 & 108 \\
\hline Europe, total & 3,822 & -6 \\
\hline Russia & 568 & 1744 \\
\hline
\end{tabular}

As could be seen from table 1, the investment volume in Russia's hospitality real estate displayed superior growth in comparison to all European countries: the investment increased 18 times from 30,3 million euros in 2015 to 568 million euros in 2016. This drastic increase was of course largely influenced by the sale of the "Gorky Gorod" sky resort by Sberbank - the largest Russian bank. The resort was built in Krasnaya Polyana in 2014 for Sochi Olympics. Nevertheless, it shows the overall trend: the market players have clearly positive expectations about investing in the hospitality industry in Russia. The main factors for that are: the sustainability of the Russian hospitality sector and the recovery of the prices after the 2014 ruble devaluation. It is important to mention that all cash flows of the Russian hotels are tied to the value of the Russian national currency - the ruble. On top of that, the returns in the Russian hospitality sector went up $14.9 \%$ in the first three quarters of 2016. It could be concluded that the growth rate and development potential of the Russian hospitality industry exceeds the numbers for Europe. Nevertheless, as was already mentioned on the Russian hospitality market, it is rather difficult for the investor to make the right assessment and analysis of the investment assets. Hence it is expedient to establish a systematic approach on a national level which would provide for attracting investments necessary for the development of national hospitality industry in accordance with the world standards.

\section{The Marketing Strategies' Development and Utilization}

Marketing plays one of the key roles among the factors that affect the profitability and overall success of the tourism and hospitality business (Kotler, Ph., Bowen, J.T., Makens, 2010; Bowie, D., Buttle, F., 2004). Marketing as an entrepreneurship philosophy and as a business concept assumes a certain management culture for the business, tying together the internal and external business operations and hence ensuring not only its success in competitive struggle, but also the effective satisfaction of the market demand (Keller, K., Kotler, P., 2012; Yang, C.,C., Cheng, L.-Y., et al, 2009).

The investigation which was conducted in the field of marketing utilization as an effective means of hospitality and tourism economic sector development in Russia leads to the following, not very consoling, conclusions. When Russia was entering the path of market economy development, the realization of marketing strategies by the hospitality and tourism businesses was impeded by the absence of initial conditions for business development, market underdevelopment, and inefficient marketing in hotel operation organization. The marketing departments of the hospitality businesses, invoked to implement the marketing complex in one cycle, did not quite comprehend their functional focus and concentrated their efforts mostly on advertisement and sales.

Konstantin B. Kostin (2018), Journal of Eastern Europe Research in Business and Economics, 
With the transition to the market economy, the competitive environment in Russia started to form in all areas of economic activity, the hospitality industry being no exception. Unfortunately, the marketing strategies of the Russian tourism and hospitality businesses, which, in fact, are the main instruments in the competitive struggle, are not yet always effective and successful (Yankevich, V.S., 2008). Compliance with the main marketing principles, which, most importantly, incorporate a focus on satisfying clients' needs, has not yet become dominant in the operation of the majority of national hospitality businesses. For the representatives of the Russian service industry, liability to clients and partners, the budget and the shareholders is not always a priority. This is clearly shown by the low level of management discipline and service quality, and lack of personnel's interest in improving the quality of work.

The main problem that the Russian hospitality industry is currently facing is the establishment and development of its national hotel chains. The chain organizational form facilitates the establishment of a unified marketing system, as well as the development and adaptation of perspective standards of higher quality hospitality service. The establishment of national hotel chains serves as a catalyst for further development of the hospitality industry (Dzandzugasova, E.A., 2007). First of all, it makes it possible to apply and disseminate the high standards of the hospitality business management at the corporate level, and hence achieve an increase in their productivity and operational efficiency. Secondly, increasing the number of the chain hotels would make it possible to put competitive pressure on non-chain hotels and improve the structure of the hospitality industry in general.

The global hotel chains throughout the world, including Russia, have to operate, survive, and build up their business under tough competition, and only the competent use of all strategies the modern marketing has to offer will bring success in the service market (Oh, H., Kim, B.-Y., et al, 2004).
Successful marketing operation is impossible without marketing research, conducted on the basis of the acquiring information and the ability to work with it. When marketing research is conducted, the managers are in need of the most diverse information - regarding the market, the client base, competitors, suppliers etc.: "to manage information means to manage the future - of your own company, your business, and, at last, your own future". Engaged in the market share competitive struggle, the hotel chains invent new marketing instruments or use the traditional ones, adapted to new technologies (Kinard, B., and M. Capella, 2006). In light of the appearance of digital media and significant progress in Internet access capabilities throughout the civilized world, Internet marketing begins to play an increasing role in every day operations of all businesses, and especially in the hospitality industry (Koh, J., Kim, Y.G., 2004; Lee, F.S., Vogel, D., \& et al, 2003). All large hotel chains currently have to manage a high quality informative web-site, subject to current global trends in the field of design, usability, on-line booking, capabilities of registering guests, news dissemination via mail, via the RSS format and other services (Ye, Q., Law, R., et al, 2009). Russian marketers do not have enough experience in conducting comprehensive marketing research, strategic planning, and working with information by means of cutting edge information systems. Moreover, the owners of the Russian hotels not always and not everywhere provide the marketing departments with sufficient resource base to conduct marketing research up to the mark, applying the modern techniques.

In order to utilize marketing as a reliable success tool, the leaders and specialists of the hospitality industry in Russia have to cope with its methodology, gain the ability to creatively apply it depending on the situation, carefully study and apply the experience of the foreign colleagues.

Developing a positive image of Russia is one of the strategic marketing goals of the tourism and hospitality complex of the country. For further development of the

Konstantin B. Kostin (2018), Journal of Eastern Europe Research in Business and Economics, DOI: $10.5171 / 2018.471337$ 
tourism and hospitality industry, the formation of positive information field with the focus on tourism in the Russian Federation is critical (Eriashvili, N.D., 2008).

\section{Provisions for Value Creation via the Adoption of Advanced Technologies}

This section encompasses the technologies, whose application is at the preliminary level in the Russian hospitality industry. However, the future of any country with a highly developed service industry depends directly on their implementation. Administering the tourism and hospitality industries involves the constant search for new strategies and approaches under highly competitive operation conditions (Rockstrom, J., Steffen, W., et al, 2009; Leiserowitz, A. A., Kates, R. W., et al, 2006). Three main technological challenges for Russia will further be considered.

1) Revenue management: This is the technology used to design pricing policy based on demand forecasting, central to the efficiency of an enterprise or company (Talluri, K.T., van Ryzin G.J., 2005; Cross, R.G., Higbie, J.A., and Cross, D.Q., 2009). The main goal of this technology in the service industry is to reach the optimal balance between the demand for tourism and hospitality management services, and corresponding supply. In other words, revenue management is about creating the supply, relevant to corresponding demand (Chiang, W-C., Chen, J.C.H., et al, 2007). The management of demand forecasting and tracing defines structural, pricing, and quantitative decisions, which the relevant tourism cluster (hotel, complexes, tour operators, air carriers) has to make in order to maximize revenue. The structural decisions, including the design of a marketing policy, (in particular the determination of sales channels) offer particular tour products, including cross products and their promotional methods (Anderson, C., \& Xie, X., 2010). The marketing apparatus, that is, the efficiency and success of the marketing policy of the tourist sector companies, is mostly determined by the degree of application of these revenue management principles (Cross, R.,G., Higibie, J.,A., et al, 2011; Ng, I.C.L., 2010). Quantitative decisions are the most critical for the tour industry businesses. Unlike the retail business, poor initial decisions do not allow for future sales of former vacant airline seats or unoccupied hotel suites. Mistakes in quantitative decision making bankrupted several Russian tour operators in the very recent past. Thus, it is expedient to approach the sales of products and services, be it a hotel complex or any other tourism business, from the position of forecasting quantity. Price determination happens later, only after revenue management strategies have ascertained precisely the number of hotel suites to be demanded at each time point by the relevant customer group. Demand structure for a tourism business could be conceptualized as having 3 main components in combination: "Product", "Client", and "Time" (Hayes, D.K., Miller, A., 2011). The "Product" component encompasses the complete product line, which the tourism enterprise has to offer; The "Client" component concerns defining and segmenting the clients into categories; the "Time" component is especially critical, because the tourism product has a much more limited lifecycle than other goods and services. The main challenge for the hospitality and tourism industry lies in providing the synergy among all 3 components, because of their high level of correlation. Therefore, a comprehensive and in-depth approach to the establishment and implementation of an efficient revenue management system required for tourism embraces four levels, as presented in Fig. 1 (Allenby et al, 1999; Rossi, P., et al, 2006).

Konstantin B. Kostin (2018), Journal of Eastern Europe Research in Business and Economics, DOI: $10.5171 / 2018.471337$ 


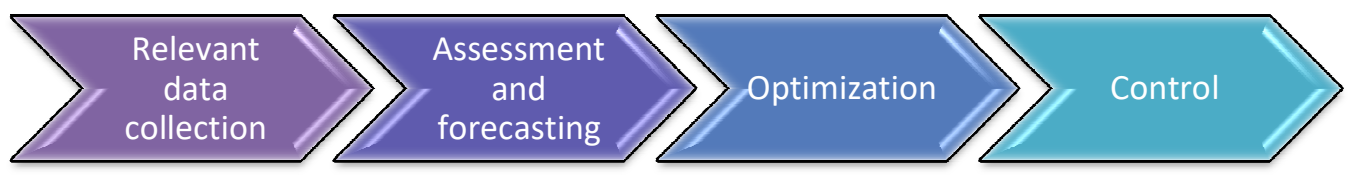

Fig. 3: The revenue management architecture for the tourism industry

\section{(Created by author)}

The first level assumes the design of a sophisticated relevant data collection system. For example, in a hospitality complex it is expedient to collect maximum data related to the guests: duration of their stay, services provided, as well as maximum information on their income, occupation, marital status, contact information etc. The more complete the information is at the system's input, the more accurately the information can be assessed and the more precise the result can be at the output. The second and third levels represent the software conceptualization of the mathematical algorithm, designed specifically for the needs of the industry. The algorithm performs the estimation, forecast and optimization, and hence provides the design for the optimal demand model which includes the given services. The optimization mechanism operates through the introduction of a set of weight coefficients, which define certain boundaries; for example, which discount systems could be successfully launched etc. An example of such an algorithm is the least mean square (LMS) algorithm (Goodman, S., Hedetniemi, S., 1977) which was successfully applied for other applications, described in (Kostin, K.B., Sokolov, V.K., 2002). It takes the LMS algorithm a fraction of a millisecond to perform thousands of iterations as defined by the optimally selected weight coefficients. The fourth level - where output data are controlled - is responsible for service distribution among the corresponding consumer marketing segments. The correctly comprised algorithm insures the best output solution, which allows timely adjustment of the pricing policy, and hence the most revenue.
The comprehensive revenue management technology implementation in the Russian hospitality business could provide it with considerable advantages over competitors and also open possibilities of further development.

2) Overbooking. In order to resolve the revenue management problem of hotel room sales (since they are considered to be the main revenue source of any hotel), the overbooking strategy is utilized (Chatwin et al, 1999), i.e. accepting the requests from potential clients in larger volumes than actual capacity. The main problem with this strategy which the majority of the hospitality complexes currently face is in the formation of spaces or gaps, where rooms are not used in between bookings, even though the total number of reservations exceeds the hotel capacity. Most of the software designed to solve the tasks of overbooking assigns existing available rooms, which satisfies the reservation criteria for particular bookings. The problem with this approach arises when reservations are cancelled, because often it is impossible to reassign the rooms within limits of reservation times, even though the demand for the room remains high. Thus while other rooms of the same type may be booked out, the program does not support their redistribution. Unfortunately, even the large 5 star hotels do not currently have a multifactorial computerized system, which allows the head of the reservations department, based on the electronic database, to effectively adapt to the changes in the booking array and hence forecast the placement of individual guests or groups at least one week in advance. Naturally, the leading global hotel chains are attempting greater 
systems integration in order to regulate the profitability of each hotel room not manually, but via an automatic electronic system (Blinova, E., 2009). They are taking relevant steps in this direction. However, their realization, especially in Russia, is far from being perfect.

3) RFID technology. One of the primary goals of the global hospitality business is the intensive implementation and utilization of the cutting edge information technologies. Information technologies allow advancing planning and enhancing the financial performance, providing for superb operational management, facilitating the hotels' occupancy, and increasing the quality of service (Noone, B.M., Mattila, A.S., 2009). One of these technologies, which fully satisfies the above mentioned requirements, is the Radio Frequency Identification (RFID) - the technology which allows the automatic identification of objects, uses radio signals which read and record the data and store it in the so-called transponders or RFID tags (Wikipedia, 2017). For the shareholders of the global hotel chains, it becomes more and more obvious that RFID technology represents a powerful tool for not only optimizing the operational processes but also substantially increasing their revenue. On that basis, the full inventory automation cycle problem could be resolved, including the itemized report generation of items, along with program integration of these cycles encompassing the accounting system of any hospitality complex. RFID utilization leads to operation enhancement of any production cycle crucial to the hotel management (Muta, 2006). Moreover, in the hospitality business, the RFID technology is a powerful driver of revenue management helping to eliminate the effect of the "lost profit". The revenue management principles combined with RFID technology serve as a foundation for the creation of appealing loyalty programs etc.

Practical experience shows that investment in RFID adoption pays off quickly, therefore its implementation in the operation of large hotel complexes is being conducted rather rapidly (Kinsella, B., 2003). In Russia the majority of the systems use the bar-code and magnetic means of identification and not RFID technology. So far, the widest presence of RFID technologies in Russia can be observed in the area of restricting access control, electronic payments via smart-cards, security systems in cars, transport identification, and electronic key system implementation in residential and commercial premises.

We believe that RFID technology adoption by the Russian hospitality complexes will contribute to their competitiveness and further successful development. As time goes by, this technology should be widely adopted by the Russian hospitality industry.

\section{Training of Personnel}

Lack of qualified staff is one of the most acute problems in the Russian service industry. The transition to the market economy and total redesign of the hospitality industry in the country demands a complete shift in the ideology of staff training. The modern global computerized hotel business can only be managed by highly qualified specialists with deep knowledge of the international hospitality management and basic information technologies along with the broad range of vision and practical skills acquired during higher education (Barron, P., 2008; Berkes, F., 2009; Popov, A.E., Plotnikov, V.A., 2013). Unfortunately, insufficient financing, increasing corruption in the field of higher education in Russia, increase in the number of private, often unaccredited Universities in the post Soviet period undermine its value and quality as well as impede the utilization of new information-educational technologies and international experience (Kirillova, O.Y., 2006) in the education process. The international experience could prove invaluable when training the young professionals for the tourism and hospitality business (Miller, M., Mao, Z., et al, 2010). At present, there are over 100 higher educational institutions in Russia which are haphazardly involved in training the specialists for hospitality industry. However the quality of teaching and

Konstantin B. Kostin (2018), Journal of Eastern Europe Research in Business and Economics, DOI: $10.5171 / 2018.471337$ 
education, as a rule, is far from approaching the world standards. The country practically lacks profound scientific schools, and a number of universities clearly lack sufficient facilities.

In order to bring the Russian Higher Education System to the world standards (which is especially important given the fact that Russia has signed the Bologna Declaration (Kanter, V.V., 2011), it is crucial to resolve this problem not at the level of each individual university, but rather on the National level. It is suggested, that the acute measures that need to be taken immediately should be: salary increase for the instructors up to the Western pay level; provisions with all modern technological means necessary for effective instruction; implementation of comprehensive motivation system both for students and for instructors; simultaneous introduction of competitive selection process for the entrants as well as for instructors as part of the hiring process.

\section{Russian Hospitality Industry Development Forecast}

Based on the conducted analysis, the hospitality industry in Russia is considerably less advanced than that of the developed countries. However, as a whole, despite a certain slow-down in the level of hotel and tourism business state (as a consequence of 2008 financial crisis and the weakening of national currency in 2014), the companies which opted for optimal models of management, carefully selected their staff and strived for optimal price-to quality correlation, are continuing to operate in the market. The comprehensive change of Russian hospitality industry structure via the increase of the number of hotel chains on the national scale will enhance opportunities to improve management efficiency for the hospitality industry as well as promote novel technologies and standards of hotel operation at the corporate level, thus improving the quality of service.

Nontraditional business approaches, which incorporate the national (Russian) specifics, local legislation, local economic conditions, pricing based on revenue management principles, comprehensive marketing and overbooking strategies could create invaluable competitive advantages for Russian hospitality operators in the process of their market share accumulation in the hospitality market. When penetrating the yet unoccupied market segments (and the potential competitors would be the international hotel chains), the national hotel operators should set the primary goal - to adopt new flexible forms of management. These new forms of management create ample opportunities for hotel product improvement, boosting consumer demand and trademark promotion. Key factors currently determining the rising demand for the services offered by the hospitality industry include: business development in the regions as well as via attraction of foreign capital; growth of the business tourism volume; increase of the appeal of Russia as the country attracting foreign travelers; improvements in the financial wellbeing of the Russian citizens, and emerging interest in domestic tourism.

The highest future growth potential of the Russian hospitality market is in forming and developing the national hotel chains, mostly in the 2-3 star segment, which escape direct competition with international hotel chains. The small business development in the mini-hotel establishments which best target the budget-minded tourists also have very good prospects. Overall, the Russian hospitality business appears to be exceptionally prospective for the diverse spectrum of entrepreneurs and investors, since it is young and carries a tremendous development potential.

\section{Conclusions}

The tourism and hospitality business is currently one of the most dynamically developing areas of the global economy. It brings multi-billion revenues to the national budgets of many countries. Russia, being the country with ample capabilities for organization of hospitality business, has

Konstantin B. Kostin (2018), Journal of Eastern Europe Research in Business and Economics, DOI: $10.5171 / 2018.471337$ 
great potential for the development of recreational, ecological and business tourism. Despite significant progress in its development, the Russian tourism and hospitality industry, in accordance with the world standards, is at the introductory stage of formation. The effective approaches to solving the existing problems could be narrowed down to the following:

1) Formation of the enterprises' investment attractiveness assessment methodology with the goal to attract investments into the tourism and hospitality business.

2) Development and utilization of effective marketing strategies.

3) Progressive technologies' adoption (revenue management, overbooking, radiofrequency identification etc.) aimed at increasing customer satisfaction and overall shareholder value.

4) Improving professional competences of the hospitality personnel.

The state of the tourism and hospitality industry is closely related with the general state of national economics. Under the market economy conditions in Russia, this area of national economics should primarily target the adoption of new perspective technologies, strategies and approaches to business management. The future development of the tourism and hospitality industry in Russia is related, on one hand, to creating the conditions for large scale business and recreational tourism development, hence further growth of the national hotel chain segment, and, on the other hand, to the small business development in the mini-hotel segment, targeting the budget tourism.

\section{References}

1. Allenby, G., Rossi, P. (1999), 'Marketing models of consumer heterogeneity,' Journal of Econometrics 89, 57-78.

2. Aleshin, V.,A., Zotova, A.,I., Nekrasova I.,V. (2010) Investment management: Study book. Rostov on Don: YuFU Publishing.

3. Anderson, C., Xie, X. (2010), Improving hospitality sales: Twenty-five years of revenue management. Cornell Hospitality Quarterly 51(1), 53-67.

4. Avanusova, G.A. (2007), Service activity: Historical and modern practice, entrepreneurship, management. AspectPress.

5. Barron, P. (2008), 'Education and talent management: Implications for the hospitality industry', International Journal of Contemporary Hospitality Management, 20(7), 730-742.

6. Berkes, F. (2009), 'Evolution of comanagement: role of knowledge generation, bridging organizations, and social learning', Journal of Environmental Management, 90, 1692-1702.

7. Blinova, E. ( 2009), 'Managing revenue', Five stars 12, 24-28.

8. Block, S.B., Hirt, G.A. (2003) Foundations of Financial Management. McGraw-Hill Companies, Inc., New York.

9. Bowie, D., Buttle, F. (2004) Hospitality marketing. Elsevier ButterworthHeinemann, Burlington MA.

10. Bragg, S.M. (2007), Business ratios and formulas: a comprehensive guide. Hoboken, N.J.,Wiley.

11. Bystrov, S.A. (2008) Financial management in tourism: textbook for students of Higher education Institutions. Publishing house Gerda.

12. Chatwin, R.E. (1999), 'Continuoustime airline overbooking with timedependent fares and refunds', Transportation Science, 33, 805-819.

13. Cheng-Hua, T., Shyh-Jer, C. and ShihChien, F. (2009), 'Employment modes, high-performance work practices, and organizational performance in the hospitality industry,' Cornell Hospitality Quarterly, 50 (4), 413-431.

14. Chiang, W-C., Chen, J. C. H. and Xu, X. (2007), 'An overview of research on revenue management: Current issues and future research,' International Journal of Revenue Management, 1(1), 97-128.

15. Cochrane, J. (2010), 'The sphere of tourism resilience,' Tourism Recreation Research, 35(2), 173-186.

16. Cross, R. G., Higibie, J. A. and Cross, Z. N. (2011), 'Milestones in the application of analytical pricing and revenue management,' Journal of Revenue and Pricing Management, 10(1), 8-18.

Konstantin B. Kostin (2018), Journal of Eastern Europe Research in Business and Economics, DOI: $10.5171 / 2018.471337$ 
17. Cross, R.G., Higbie, J.A. and Cross, D.Q. (2009), 'Revenue management's renaissance: A rebirth of the art and science of profitable revenue generation,' Cornell Hospitality Quarterly 50(1), 56-81. 18. Dzandzugasova, E.A. (2007) Marketing in hospitality industry. E. M.: Academy.

19. Eriashvili, N.D. (2008) Management and marketing M: Yunety-Dana.

20. Fabozzi, F.J., Markowitz, H.M. (2011)

The Theory and Practice of Investment Management. Second Edition, John Wiley \& Sons, Inc.

21. Farrell, B., Twining-Ward, L. (2005),'Seven steps towards sustainability: Tourism in the context of new knowledge,' Journal of Sustainable Tourism, 13, 109122.

22. Geraschenko, E. (2016), "Investors were leaned into the suites. Investments into Russian hotels went up 18 times,' Kommersant. [Online], [Retrieved May 25, 2017]

https://www.kommersant.ru/doc/314447 8

23. Glen, Arnold. (2007) The Handbook of Corporate Finance: A Business Companion to Financial Markets, Decisions \& Techniques.

24. Goodman, S., Hedetniemi, S. (1977) Introduction to the Design and Analysis of Algorithms. McGraw-Hill, New York.

25. Hayes, D.K., Miller, A. (2011) Revenue Management for the Hospitality Industry. John Willey and Sons.

26. Heide, M., Gronhaug, K. (2009), 'Key factors in guests' perception of hotel atmosphere,' Cornell Hospitality Quarterly 50 (1), 29-43.

27. InterContinental Hotels Group (IHG), (2011), “Annual Report," [Online], [Retrieved November 01, 2013], http://www.ihgplc.com/

28. Jackson, Ch. (2006) Active Investment Management: Finding and Harnessing Investment Skill. John Wiley \& Sons Ltd, the Atrium, Southern Gate, Chichester, West Sussex P019 8SQ England.

29. Johannesson, J., Palona, I. (2010), 'The dynamics of strategic capability,' International Business Research, 3(1), 312.

30. Kang, K.H., Lee, S. and Huh, C. (2010), 'Impacts of positive and negative corporate social responsibility activities on company performance in the hospitality industry,' International Journal of Hospitality Management 29 (1), 72-82.

31. Kanter, V.V. (2011), 'Two level system of education, legal aspects,' Young scientist 2(12), 9-11.

32. Keller, K., Kotler, P. (2012) Marketing management. New Jersey: Pearson Education Inc.

33. Kirillova, O.Yu. (2006), 'Antagonisms and development prospects of the Russian education system,' Successes of modern natural history, 10, 27-29.

34. Kinard, B., Capella, M. (2006), 'Relationship marketing: The influence of consumer involvement on perceived service benefits,' Journal of Service Marketing, 20 (6), 359-368.

35. Kinsella, B. (2003), 'The Wal-Mart factor,' Industrial Engineer, 35(11), 32-36.

36. Koh, J., Kim, Y.G. (2004), 'Knowledge sharing in virtual communities: an ebusiness perspective,' Expert Systems with Applications, 26 (2), 155-166.

37. Kotler, Ph., Bowen, J.T., Makens, J.C. (2010) Marketing for Hospitality and Tourism. Prentice Hall PTR.

38. Kostin, K.B. (2012), 'The current main management and development trends in the hospitality industry of Russia,' Ekonomicheskoe Vozrozdenie Rossii Journal,1(31), 72-81.

39. Kostin, K.B. (2016) Marketing methodology and tourism business effectiveness on the Russian market of tourism services. Monograph. SaintPetersburg. Polytechnic University Publishing.

40. Kostin, K.B. (2012), 'Investment attractiveness assessment strategy formation in the system of tourism business management,' Vestnik RAEN, 16(3), 88-93.

41. Kostin, K.B., Sokolov, V.K. (2002), 'Mathematical modeling of an adaptive acousto-optic interference canceller,' Proc. SPIE, 5066, 265-272.

42. Lee, F.S., Vogel, D. and Limayem, M. (2003), 'Virtual community informatics: A review and research agenda,' The Journal of Information Technology Theory and Application, 5 (1), 47-61.

43. Leiserowitz, A. A., Kates, R. W. and Parris, K. M. (2006), 'Sustainability values,

Konstantin B. Kostin (2018), Journal of Eastern Europe Research in Business and Economics, DOI: $10.5171 / 2018.471337$ 
attitudes, and behaviors: A review of multinational and global trends,' Annual Review of Environment and Resources, 31, 414-444.

44. Linea, Nathaniel D., Runyan, Rodney C. (2012), 'Hospitality marketing research: Recent trends and future directions,' International Journal of Hospitality Management, 31, 477-488.

45. Mel'nikov, D.,V. (2012), 'The territorial and social interaction under Russian statemarket economy'. Book of Abstract 6 ${ }^{\text {th }}$ ERIS Conference. 10-12 October, Kuopio, Finland. (ed), A. Baldshun, A.Jaakola, L. Leinonen. Published by ERIS.

46. Mel'nikov, D.,V. (2011), 'Federal Districts of Russia: economic aspects,' Vestnik of the Tomsk State University. Economy, 3 (15), 156-170.

47. Miller, M., Mao, Z. and Moreo, P. (2010), 'Hospitality \& tourism educators vs. the industry: A competency assessment,' Journal of Hospitality and Tourism Education, 22 (2), 38-50.

48. Muta, (2006), "The Promise and Opportunity of RFID,' Hospitality Upgrade. [Online], [Retrieved January 11, 2013], http://www.hospitalityupgrade.com/_mag azine/magazine_Detail.asp?ID $=21$

49. Noone, B.M., Mattila, A.S. (2009), 'Hotel revenue management and the Internet: the effect of price presentation strategies on customers' willingness to book,' International Journal of Hospitality Management 28 (2), 272-279.

50. Ng, Irene C.L. (2010), 'The future of pricing and revenue models,' Journal of Revenue and Pricing Management, 9, 276281.

51. Oh, H., Kim, B.-Y. and Shin, J.-H. (2004), 'Hospitality and tourism marketing: recent developments in research and future directions,' International Journal of Hospitality Management 23 (5), 425-447.

52. Popov, A.I., Plotnikov, V.A. (2013), 'The choice of the new model and modernization: the foundations for transition to innovation economics,' Proceedings of the Saint-Petersburg State University of Economics and Finance 2 (74), 197-209.

53. Putilina E.L. (2011), 'History of international hospitality industry development,' Proceedings of the State University of Management 12, 14-18.
54. 'Radio-frequency identification,' From Wikipedia, the free encyclopedia. [Online], [Retrieved January 3, 2017], http://en.wikipedia.org/wiki/Radio-

frequency_identification

55. Russian hotel market reports strong start to 2017. (2017), Russia hotel and tourism investment conference. [Online], [Retrieved January 3, 2017] http://www.russia-conference.com/pressreleases/russian-hotel-market-reportsstrong-start-to-2017

56. Rockstrom, J., Steffen, W., Noone, K., Persson, A., III Chapin, F. S., Lambin, E., et al. (2009), "A safe operating space for humanity,' Nature, 461, 472-475.

57. Rossi, P., Allenby, G., and McCulloch, R. (2006) Bayesian Statistics and Marketing. John Willey \& Sons Ltd, The Atrium, Southern Gate, Chichester, West Sussex P01985Q, England.

58. ROSSTAT: Hotels, hostels and models. Statistical wonders and 17 years of history. What is happening with alternative accommodations. Hoteiler. [Online], [Retrieved January 5, 2018], http://hotelier.pro/tourizm/item/2973rosstat

59. Russian statistical yearbook 2017. Statistical handbook. Federal State Statistics service. [Online], [Retrieved January 10, 2018], http://www.gks.ru/free_doc/doc_2017/ye ar/year17.pdf

60. Skobkin S.S. (2002), 'The goals and tasks of marketing for the Russian hospitality industry,' Russian Entreprenuership, 2, 1-15.

61. Shubaeva V.G., Burova N.V. (2013), 'Region's attractiveness indicators as a tourist destination and the marketing strategy for its development,' Proceedings of the Saint-Petersburg State University of Economics and Finance 2(74), 124-127.

62. Susilovic, A. and Sertic, M. (2010), 'Impact of economic crisis on tourism demand.' Faculty of Tourism and Hospitality Management in Opatija. Biennial International Congress. Tourism and Hospitality Industry Conference Proceedings, University of Rijeka, Croatia. 63. Talluri, K.T., van Ryzin G.J. (2005) The Theory and Practice of Revenue Management. Springer.Tkacheva, Ya.,S. (2011), ' Investment attractiveness

Konstantin B. Kostin (2018), Journal of Eastern Europe Research in Business and Economics, DOI: $10.5171 / 2018.471337$ 
components' characteristics of region's recreational-tourist enterprise complex,' Creative Economy 2 (50), 105-110.

64. Travel and Tourism. Economic Impact 2017. Russian Federation. World Travel and Tourism Council. [Online], [Retrieved January 3, 2017] https://www.wttc.org//media/files/reports/economic-impactresearch/countries-

2017/russianfederation2017.pdf

65. Vlasova, T.V. (2013), 'Small business and tourism infrastructure development,' Proceedings of Saint-Petersburg State University of Economics and Finance 2(74), 50-53.
66. Yang, C.-C., Cheng, L.-Y., Sung, D. and Withiam, G. (2009), 'Strategic-pricing policy based on analysis of service attributes,' Cornell Hospitality Quarterly 50 (4), 498-509.

67. Yankevich, V.S. (2008) Marketing in hospitality industry and tourism: Russian and international experience. M.: Finance and Statistics.

68. Ye, Q., Law, R., Gu, B. (2009), 'The impact of online user reviews on hotel room sales,' International Journal of Hospitality Management 28 (1), 180-182.

Konstantin B. Kostin (2018), Journal of Eastern Europe Research in Business and Economics, DOI: $10.5171 / 2018.471337$ 